\title{
Characterization of airag collected in Ulaanbaatar, Mongolia with emphasis on isolated lactic acid bacteria
}

\author{
Suk-Ho ChoidD
}

\begin{abstract}
Background: Airag, alcoholic sour-tasting beverage, has been traditionally prepared by Mongolian nomads who naturally ferment fresh mares' milk. Biochemical and microbiological compositions of airag samples collected in Ulaanbaatar, Mongolia and physiological characteristics of isolated lactic acid bacteria were investigated.

Methods: Protein composition and biochemical composition were determined using sodium dodecyl sulfate-gel electrophoresis and high performance liquid chromatography, respectively. Lactic acid bacteria were identified based on nucleotide sequence of $16 \mathrm{~S}$ rRNA gene. Carbohydrate fermentation, acid survival, bile resistance and acid production in skim milk culture were determined.

Results: Equine whey proteins were present in airag samples more than caseins. The airag samples contained 0.10$3.36 \%$ lactose, $1.44-2.33 \%$ ethyl alcohol, 1.08-1.62 \% lactic acid and $0.12-0.22 \%$ acetic acid. Lactobacillus (L.) helveticus were major lactic acid bacteria consisting of 9 isolates among total 18 isolates of lactic acid bacteria. $L$. helveticus survived strongly in PBS, pH 3.0 but did not grow in MRS broth containing $0.1 \%$ oxgall. A couple of $L$. helveticus isolates lowered pH of skim milk culture to less than 4.0 and produced acid up to more than $1.0 \%$.

Conclusion: Highly variable biochemical compositions of the airag samples indicated inconsistent quality due to natural fermentation. Airag with low lactose content should be favorable for nutrition, considering that mares' milk with high lactose content has strong laxative effect. The isolates of $L$. helveticus which produced acid actively in skim milk culture might have a major role in production of airag.
\end{abstract}

Keywords: Airag, Koumiss, Lactic acid bacteria, Lactose, Acid production

\section{Background}

Airag, also called either koumiss or chigee, is a popular beverage traditionally produced in central Asian regions including Kazakhstan, Krygyzstan, some central regions of Russia and Xinjiang, Inner Mongolia and Qinghai of China as well as Mongolia. It is a mildly alcoholic, sour-tasting fermented drink made from unpasteurized fresh mares' milk. Old airag made in the previous year or freshly prepared airag is mixed with fresh mares' milk at the rate of $20 \%$ [1]. The mixture is kept in a suitable bag which is made of animal hide. During fermentation, regular beating and storage temperature at $20-30{ }^{\circ} \mathrm{C}$ are required in order to produce acid, ethanol and flavors. The fermentation results in up to $2 \%$ ethyl alcohol content and low pH less than 4 [2].

Correspondence: shchoi@sangji.ac.kr

Animal Science and Biotechnology, Sangji University, Wonju 26339, South Korea
The major microorganisms in airag have been shown to be lactobacilli and yeasts in previous studies [3-6]. Lactobacilli convert lactose into lactic acid to acidify mares' milk to provide refreshing sour taste. Yeasts ferment the sugar into ethyl alcohol and carbon dioxide to produce carbonated mildly alcoholic drink. The mixed culture of lactobacilli and yeasts in airag seems to enhance cell growth and fermentation better than single culture [7]. The ability of Kluyveromyces marxianus to utilize lactose effects its dominant growth in milk $[3,5]$. The major Lactobacillus species isolated from airag of Mongolia and China is Lactobacillus helveticus, Lactobacillus plantarum, and Lactobacillus casei [4, 8-10]. The proportions of the Lactobacillus species in airag seem to be affected by recipes to prepare starter cultures for airag production and by geographical location $[5,11]$. 
For long centuries, airag has been recognized as a wholesome beverage which influences alimentary canal, circulation system and immune system. Airag is claimed to belong to functional foods that provide health benefits [12], which result from high contents of polyunsaturated fatty acids in mares' milk and probiotic microorganisms as well as basic nutrients, such as calcium and protein [13-15]. However, mares' milk has been recognized as a strong laxative because of high content of lactose which cannot be digested and absorbed in the small intestine of most Asians in adult age. Since lactose can be decomposed into lactic acid and ethanol during fermentation, airag may not cause diarrhea and abdominal cramp, which are frequent symptoms of lactose intolerance.

The objectives of this study were to investigate microbiological and biochemical characteristics of airag samples collected in Ulaanbaatar, Mongolia and to determine physiological property and growth in skim milk of isolated lactic acid bacteria which might play major roles in producing acid in airag.

\section{Methods}

\section{Sample collection}

The airag samples were collected from Ulaanbaatar, Mongolia in 2013 and 2014. The samples were put into sterile polyethylene tubes and kept cold in an ice box during transportation by air to Laboratory of Food Biotechnology in Sangji University. Microbiological analysis of the samples stored at $4{ }^{\circ} \mathrm{C}$ was performed within a week of collecting them. The frozen samples were used for SDS-PAGE and HPLC.

\section{Enumeration and isolation of microorganisms}

BCP plate count agar (Eiken Chemical, Japan) supplemented with $0.01 \%$ cycloheximide and yeast malt extract agar supplemented with $0.01 \%$ chloramphenicol [5] were used to enumerate lactic acid bacteria and yeasts, respectively. Enumeration was performed by spreading $0.1 \mathrm{~mL}$ of samples diluted with $0.1 \%$ peptone on the agar plate. The plates for counting lactic acid bacteria and yeasts were incubated anaerobically at $32{ }^{\circ} \mathrm{C}$ for 3 days and aerobically at $25^{\circ} \mathrm{C}$ for 4 days, respectively.

The diluted airag samples were spread on M17 agar (Difco, USA) which was supplemented with lactose and MRS agar (Difco, USA) which was acidified to pH 5.2. The M17 agar and MRS agar were then incubated anaerobically at $32{ }^{\circ} \mathrm{C}$ for 3 days to isolate enterococci and lactobacilli, respectively from the airag samples [16, 17]. The isolated colonies were scraped from the agar plates and suspended in skim milk. Equal volume of $20 \%$ glycerol and skim milk was added to the suspension, which was then stored at $-80^{\circ} \mathrm{C}$.

\section{Identification of lactic acid bacteria}

Lactic acid bacteria were identified by sequencing $16 \mathrm{~s}$ rRNA gene and then by using BLAST search program (National Center of Biotechnology Information, USA). The sequencing experiments were provided by Solgent Co., Ltd, in Korea. The procedure was described briefly as follows: Genomic DNA was extracted from colonies on the agar plates by using purification beads (Solgent, Korea). The partial sequence from the forward primer $27 \mathrm{~F}$ was determined by using Bigdye terminator cycle sequencing kit (Perkin-Elmer, USA) and ABI Prism 3730x1 DNA Analyzer (Perkin-Elmer, USA).

\section{Phylogenetic relationship between lactobacilli}

The partial sequences of 16S RNA genes of lactobacilli were modified by removing sequences at $5^{\prime}$-end and $3{ }^{\prime}$ end to obtain a $909 \mathrm{bp}$-long sequence with $5^{\prime}$-ggggcccgcacaagcggtgg- $3^{\prime}$ at $3^{\prime}$-end. The resulting sequences of the isolates were subjected to multiple sequence alignment programs of multiple alignment using fast fourier transform(MAFFT) which were provided by Kyoto University Bioinformatics Center(KUBC) and European Molecular Biology Laboratory(EMBL). A diagram of rooted phylogenetic tree with branch length and percent identities between lactobacilli were obtained from the programs provided by KUBC and EMBL, respectively.

\section{Physiological characteristics of lactic acid bacteria}

Physiological characteristics were examined following the methods described by Harrigan and McCane [18]. Studies to determine ability of enterococci to grow at $10{ }^{\circ} \mathrm{C}$, at $45{ }^{\circ} \mathrm{C}$, at $\mathrm{pH} 9.6$ and in the presence of $6.5 \%$ sodium chloride and to survive heating at $60{ }^{\circ} \mathrm{C}$ for $30 \mathrm{~min}$ were performed using yeast glucose lemco broth. Production of ammonia from arginine was determined in the arginine broth. Ability of lactic acid bacteria to ferment carbohydrates was determined using MRS fermentation broth (Scharlau, Spain) which was supplemented with $2 \%$ filtersterilized carbohydrates.

\section{Acid survival of lactic acid bacteria}

Two hundred microliters of cultures in MRS broth which had been incubated at $37{ }^{\circ} \mathrm{C}$ for 24 h were suspended into $20 \mathrm{~mL}$ of phosphate buffered saline, $\mathrm{pH} 7.2$ (PBS, pH 7.2) and PBS, pH 3.0 which was acidified by adding $\mathrm{HCl}$. After incubating at $37^{\circ} \mathrm{C}$ for $3 \mathrm{~h}$, lactic acid bacteria in the suspension were enumerated by spreading diluted suspension on $\mathrm{BCP}$ plate count agar which was incubated at $37{ }^{\circ} \mathrm{C}$ for 2 days. The percent of acid survival was calculated by dividing the bacterial number of PBS, pH 3.0 with that of PBS, pH 7.2 and then by multiplying with $100 \%$ as described before [6]. 


\section{Bile resistance of lactic acid bacteria}

Two hundred microliters of the same cultures used in the study of acid survival were suspended into $20 \mathrm{~mL}$ of MRS broth without addition (MRS-control) and MRS broth containing $1 \%$ oxgall (MRS-bile). The inoculated broth was incubated at $37{ }^{\circ} \mathrm{C}$ for $24 \mathrm{~h}$. The absorbance of the culture was measured at $600 \mathrm{~nm}$. The percent of bile resistance was calculated by dividing absorbance of culture in MRS-bile with that of culture in MRS-control and then by multiplying $100 \%$ as described before [6].

\section{Preparation of frozen concentrated culture}

MRS broth containing lactose instead of glucose was prepared to produce frozen concentrated cultures of lactic acid bacteria. Lactic acid bacteria were cultured in $200 \mathrm{~mL}$ of the above broth at $37^{\circ} \mathrm{C}$ for $24 \mathrm{~h}$ and centrifuged at $200 \mathrm{xg}$ for $30 \mathrm{~min}$. The cell pellets were suspended into the equal mixture of skim milk and $20 \%$ glycerol to make about $8 \mathrm{~mL}$ of cell suspension. Aliquots of the cell suspension were dispensed into tubes and frozen in the freezer at $-80{ }^{\circ} \mathrm{C}$.

\section{Fermentation of skim milk culture}

The frozen concentrated cultures were used as inoculants for skim milk cultures of lactic acid bacteria isolated from the airag samples. Aliquots of the frozen concentrated cultures which had been thawed at room temperature immediately before experiments was added to make bacterial suspensions of $7 \log C F U / \mathrm{mL}$ in $200 \mathrm{~mL}$ of skim milk. The inoculated skim milk cultures were incubated at $25^{\circ} \mathrm{C}$, $30{ }^{\circ} \mathrm{C}$ and $37^{\circ} \mathrm{C}$ for 4 days. Samples were taken to determine $\mathrm{pH}$ and titratable acidity and to enumerate lactic acid bacteria after $0,1,2,3$ and 4 days.

Skim milk cultures of $L$. helveticus isolates which were activated by incubating serially twice at $35{ }^{\circ} \mathrm{C}$ for 1 day were used as inoculants. Two milliliters of the skim milk cultures were suspended into $200 \mathrm{~mL}$ of skim milk. The inoculated skim milk cultures were incubated at $35{ }^{\circ} \mathrm{C}$ for 3 days. Samples were taken to determine $\mathrm{pH}$ of the cultures after $0,1,2$ and 3 days.

\section{Chemical analysis}

Titratable acidity was determined by following the method described by Bradely et al. [19]. The contents of lactose, lactic acid, acetic acid and ethyl alcohol were determined by using high performance liquid chromatography (HPLC). In order to make samples for HPLC analysis, the airag samples were acidified to $\mathrm{pH} 2.0-2.3$ by adding $1 \mathrm{M}$ sulfuric acid and centrifuged to $1,000 \mathrm{xg}$ for $30 \mathrm{~min}$. The supernatants were passed through a column containing $0.2 \mathrm{~g}$ of Chelex 100 resin (Bio-Rad, USA) and filtered through a membrane filter with pore size of $0.45 \mu \mathrm{m}$. The filtrates were used as samples for the HPLC analysis. The HPLC system (Varian, USA) consisted of a solvent delivery system (9012Q), a refractive index detector (Star 9040), and a column oven (101). The temperature of Rezex ROA column with the size of $150 \times 7.7 \mathrm{~mm}$ (Phenomenex, USA) was $60^{\circ} \mathrm{C}$. The eluant was $4 \mathrm{mM}$ sulfuric acid and the flow rate was $0.6 \mathrm{~mL} / \mathrm{min}$.

\section{Sodium dodecyl sulfate-polyacrylamide gel electrophoresis (SDS-PAGE)}

SDS-PAGE of airag sample was performed following the procedure described by Laemmli [20]. The airag samples were adjusted to $\mathrm{pH} 7$ by adding $5 \mathrm{M} \mathrm{NaOH}$ and dialyzed in a cellulose membrane tubing (Sigma Aldrich, USA). Equal amounts of Laemmli's sample buffer $(2 x)$ containing $5 \% 2$-mercaptoethanol were added to the samples, which were then heated at $95{ }^{\circ} \mathrm{C}$ for $5 \mathrm{~min}$ and then subjected to the electrophoresis. Separating gel of $14 \%$ acrylamide was used for electrophoresis. Molecular weight standards (Bio-Rad, USA) used for SDS-PAGE were phosphorylase b $(97,400)$, serum albumin $(66,200)$, ovalbumin $(45,000)$, carbonic anhydrase $(31,000)$, trypsin inhibitor $(21,500)$ and lysozyme $(14,400)$. The unit of molecular weight number in parenthesis is dalton.

\section{Results and discussion}

\section{Biochemical and microbiological characteristics of airag}

The polypeptide compositions of five airag samples were investigated by using SDS-PAGE (Fig. 1), which showed that three polypeptides with molecular weights near 30,000 daltons shown in lane B, C, D, E and F were equine caseins [21], which had similar molecular weights of bovine caseins shown in lane G. Equine whey proteins consisting of $\beta$-lactoglobulin, lysozyme and $\alpha$-lactalbumin with the molecular weights of $18,800,15,500$ and 14,400 daltons, respectively, [22] were shown as major proteins in the five airag samples in the lane B, C, D, E and F. Bovine $\beta$-lactoglobulin and $\alpha$-lactalbumin with the molecular weight of 18,300 and 14,400 daltons were shown in lane G, but bovine lysozyme which exists in trace amount in cows' milk [13] could not be detected.

Equine whey proteins seemed to be major proteins in the airag samples in this study. Malacarne et al. [13] reported that the proportions of whey protein to crude protein in mares' milk and cows' milk were 38.79 and $17.54 \%$, respectively. Uniacke-Lowe et al. [23] showed that casein to whey ratios of mare milk and cow milk were 1.1 and 4.7, respectively. However, SDS-PAGE in Fig. 1 showed that the staining intensities of whey proteins in airag was stronger than those of caseins. This result suggested that equine caseins might be partially hydrolyzed during fermentation of mare's milk. It was shown that up to $10 \%$ of equine milk proteins were hydrolyzed after $96 \mathrm{~h}$ during fermentation of mares' milk [23]. Egito et al. [21] reported that equine $\alpha$ - and $\beta$ casein were susceptible to cleavage by aspartate proteases such as chymosin. 


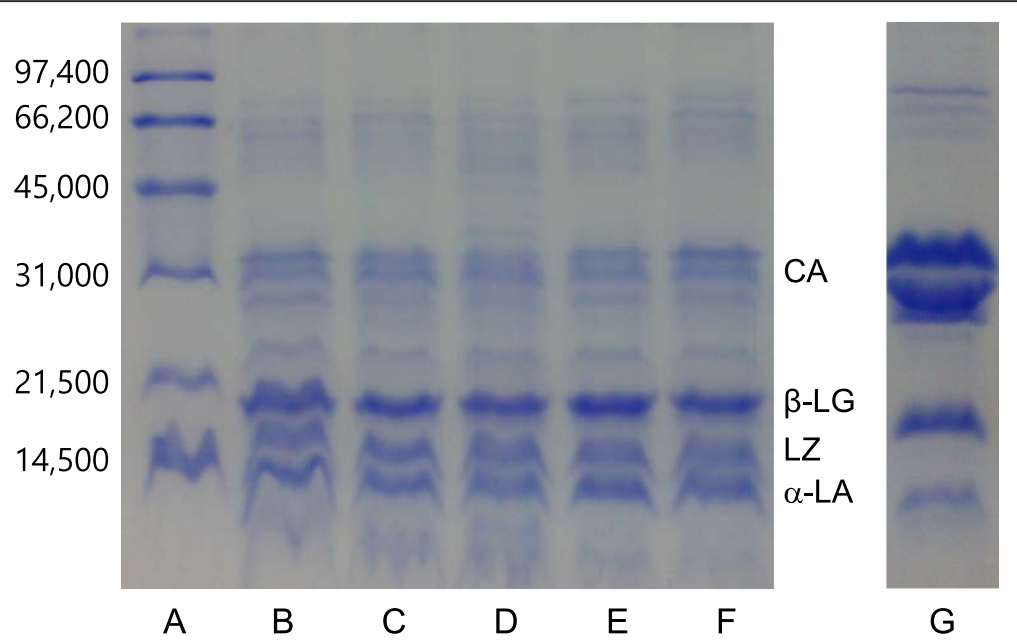

Fig. 1 SDS-PAGE of airag samples collected in Ulaanbaatar, Mongolia. A: Molecular weight standards, B-F: the airag samples 1-5, G: cows' skim milk, CA: caseins, $\beta$-LG: lactoglobulin, LZ: Iysozyme, a-LA: a-lactalbumin, The numbers at left indicate molecular weights in dalton of the standards described in materials and methods

The counts of lactic acid bacteria and yeasts in the airag samples were enumerated by using BCP plate counts agar supplemented with $0.01 \%$ cycloheximide and yeast malt extract agar supplemented with $0.01 \%$ chloramphenicol, respectively. Table 1 showed that the counts of lactic acid bacteria and yeasts and $\mathrm{pH}$ of the airag samples ranged 8.07-8.76 $\log \mathrm{CFU} / \mathrm{mL}, 6.43-7.87 \log \mathrm{CFU} / \mathrm{mL}$ and 3.533.89 , respectively. The contents of lactose, lactic acid, acetic acid and ethyl alcohol were variable among the airag samples and ranged $0.10-3.36 \%, 1.08-1.62 \%, 0.12-0.22 \%$ and 1.44-2.33\%, respectively. The airag sample 1 showed the highest numbers of lactic acid bacteria and yeasts and the highest contents of lactic acid and ethyl alcohol of all the airag samples. The airag samples 3 and 4 contained $0.1 \%$ lactose which indicated that most of lactose was spent. The airag sample 5 contained the highest amount of lactose and the lowest amount of ethyl alcohol of all the samples, which suggested deficient alcohol fermentation. Overall, the results showed that the compositions were highly variable between the airag samples suggesting inconsistent qualities due to natural fermentation.

Table 1 Microbiological and biochemical compositions of airag samples collected in Ulaanbaatar, Mongolia

\begin{tabular}{llllllll}
\hline $\begin{array}{l}\text { No. Lactic acid } \\
\text { bacteria } \\
\text { logCFU/mL }\end{array}$ & Yeasts & pH & Lactose & $\begin{array}{l}\text { Lactic } \\
\text { acid }\end{array}$ & $\begin{array}{l}\text { Acetic } \\
\text { Acid }\end{array}$ & $\begin{array}{l}\text { Ethyl } \\
\text { alcohol }\end{array}$ \\
\hline 1 & 8.76 & 7.87 & 3.53 & 0.78 & 1.62 & 0.12 & 2.57 \\
2 & 8.04 & 7.41 & 3.89 & 1.56 & 1.14 & 0.22 & 2.38 \\
3 & 8.54 & 7.66 & 3.71 & 0.10 & 1.36 & 0.15 & 2.04 \\
4 & 8.23 & 6.43 & 3.66 & 0.11 & 1.28 & 0.08 & 2.15 \\
5 & 8.07 & 7.61 & 3.88 & 3.36 & 1.08 & 0.16 & 1.44 \\
\hline
\end{tabular}

Sun et al. [4] reported that the counts of lactic acid bacteria and yeasts of the airag samples collected in Ulaanbaatar region of Mongolia ranged from 6.88 to 7.38 $\log \mathrm{CFU} / \mathrm{g}$ and 5.49 to $6.11 \log \mathrm{CFU} / \mathrm{g}$, respectively. $\mathrm{pH}$ ranged 3.7 to 4.1. Watanabe et al. [5] showed that 22 airag samples collected from Steppe, Forest-steppe, Gobi and Desert in Mongolia contained populations of lactic acid bacteria and yeasts at 7.78 and $7.41 \log \mathrm{CFU} / \mathrm{mL}$, respectively. $\mathrm{Mu}$ et al. [3] reported that 96 koumiss samples of China harbored yeast populations at $5-7 \log \mathrm{CFU} / \mathrm{mL}$. The microbiological characteristics of the airag samples in this study showed that the yeast counts were similar with those reported by the previous studies [3-5], but the lactic acid bacteria counts were higher than those reported by Sun et al. [4] and Watanabe et al [5]. The $\mathrm{pH}$ of the airag samples were lower than those reported by Sun et al. [4]. Thus, it seemed that the airag samples in this study underwent extended growth of lactic acid bacteria and strong production of lactic acid.

Table 1 showed that most of the airag samples contained low amounts of lactose. Thus, intake of airag shall not cause symptoms of lactose intolerance, even though mares' milk with $6.4 \%$ lactose [13] has strong laxative effects. Mongolian tradition of drinking airag as a staple food during summer seems to be an appropriate way to take in essential nutrients, such as calcium, vitamin, protein and essential fatty acid rich in mares' milk [13-15] and probiotics present in airag $[6,9]$.

\section{Identification of lactic acid bacteria isolated from airag}

Lactobacilli and enterococii were isolated by inoculating MRS agar acidified to $\mathrm{pH} 5.2$ and M17 agar containing lactose, respectably, with the airag samples diluted with $0.1 \%$ peptone and then by incubating anaerobically at $32^{\circ}$ 
$\mathrm{C}$ for 3 days. Eighteen isolates were identified based on 99-100 \% of percent identity which was obtained by analyzing partial sequences of $16 \mathrm{~S}$ rRNA gene on BLAST tool. Nine isolates of Lactobacillus (L.) helveticus SJU1-9, two isolates of L. kefiranofaciens SJU10-11, two isolates of L. kefiri SJU12-13, and an isolate of L. diolivorans SJU14, two isolates of Enterococcus (E.) faecalis SJU 15-16, an isolate of E. faecium SJU17 and an isolate $E$. durans SJU18 were identified. GenBank accession numbers of the partial sequences of $16 \mathrm{~S}$ rRNA gene of the isolates, SJU1-18, are KT368983-KT369000, respectively.

Previous studies also showed that all the airag samples collected in various regions of Mongolia contained $L$. helveticus as predominant lactic acid bacterial species $[4,5,9,10]$. L. helveticus (19 isolates), L. plantarum (6 isolates) and L. casei (1 isolate) from five airag samples collected at households in Ulaanbaartar, Mongolia were identified by Sun et al. [4]. The major lactic acid bacteria of airag samples collected from three nomadic families in Donto-Govi prefecture in Mongolia consisted of L. helveticus and L. kefiri [10]. Watanabe et al. [5] reported that L. helveticus $(21 / 22)$ and L. kefiranofaciens (14/22) were major lactic acid bacteria isolated from 22 airag samples in Mongolia. Takeda et al. [9] isolated 67 lactic acid bacteria from 7 airag samples collected in Ulaanbaatar, Mongolia. $L$. helveticus, $L$. delbrueckii ssp. lactis, and L. fermentum were dominant species at the levels of $46.2 \%, 22.4 \%$, and $11.9 \%$, respectively.

However, An et al. [24] reported that L. plantarum, $L$. pentosus and Lactococcus lactis ssp. cremoris were the major lactic acid bacteria in chigee collected in Inner Mongolia, China at the rate of 48, 33 and $19 \%$, respectively. Wu et al. [6] reported that dominant lactobacilli species in koumiss sampled in Inner Mongolia, China were $L$. casei, L. helveticus and L. plantarum at the levels of 35,21 , and $17 \%$, respectively. Sun et al [8] reported that $L$. helveticus, $L$. casei, and $L$. plantarum appear to be dominant species in koumiss collected in Xinjiang, Inner Mongolia and Qinghai, China, respectively. These studies showed that the main lactobacilli in the koumiss samples collected in China were diverse and different from those in Mongolia.

There are many types of fermented milk including yogurt which is manufactured industrially in many countries by using defined cultures containing Streptococcus thermophilus and L. delbrueckii ssp. bulgaricus [25]. Kefir is a drink which is prepared from cows' milk by using kefir grains as a starter culture which consists of Lactococcus lactis, L. acidophilus, L. kefir, L. kefiranofaciens, L. casei, Candida kefyr, Kluyveromyces marxianus and Saccharomyces cerevisiae. Kefir contains $0.5-1.0 \%$ ethyl alcohol, whereas the airag samples in this study contained $1.44-2.33 \%$. Koumiss is also manufactured commercially by using various lactic acid bacteria and Kluyveromyces marxianus as starter [25]. Three types of koumiss exist, so-called 'strong,'moderate' and 'light' koumiss depending on the lactic acid contents [26]. 'Strong 'koumiss is generated by lactic acid bacteria, such as L. delbrueckii ssp. bulgaricus, which acidify the milk to $\mathrm{pH}$ 3.6-3.3.'Moderate' koumiss contains lactic acid bacteria, such as $L$. acidophilus, L. plantarum and L. casei that lower the $\mathrm{pH}$ to 4.5-3.9. 'Light' koumiss is a slightly acidified product with $\mathrm{pH} 4.5-5.0$ and harbors Lactococcus lactis and Streptococcus thermophiles. The airag samples in this study could be classified as 'moderately strong' koumiss.

\section{Phylogenetic relationship analysis}

Phylogenetic relationships among lactobacilli including the isolates from the airag samples and other lactobacilli used as commercial starter cultures for yogurt and probiotics were determined by comparing the partial nucleotide sequences of $16 \mathrm{~S}$ rRNA genes of $909 \mathrm{bp}$ in the multiple sequence alignment program of MAFFT. The MAFFT analysis showed that the sequences adjacent to the 5 '-end of the partial sequences of $16 \mathrm{~S}$ rRNA genes were highly variable among the lactobacilli, but the sequences adjacent to the 3 '-end were similar each other (data not shown). Figure 2 showed a diagram of rooted phylogenetic tree with branch length and percent identity numbers which were derived from the MAFFT analysis. The diagram showed that $L$. helveticus and $L$. kefiranofaciens were closely related with each other at $99 \%$ identity and moderately associated at $97 \%$ identity with $L$. acidophilus. L. diolivorans and $L$. kefiri showed moderate relationship at $97 \%$ identity. The phylogenetic relationship of the lactobacilli in Fig. 2 corresponded to the classification proposed by Hammes and Hertel [27]. L. helveticus, L. kefiranofaciens and L. acidophilus belongs to Group A lactobacilli which is obligately homofermentative. L. diolivorans and L. kefiri are among Group B lactobacilli which is facultatively heterofermentative.

L. acidophilus is one of the important probiotics used to produce therapeutic fermented milks [28]. Many studies showed that L. helveticus and L. kefiranfaciens were also good candidates to become probiotics. The species of $L$. helveticus are highly proteolytic lactic acid bacteria which produce peptides which possess inhibitory activity on the angiotensin converting enzyme (ACE) $[29,30]$ and are traditionally used in the manufacture of Swiss-type cheeses and long ripened Italian cheeses [31]. L. kefiranfaciens was reported to produce polysaccharide, e.g. kefiran, which exerts hypocholesterolemic and hypotensive effects [32, 33]. 


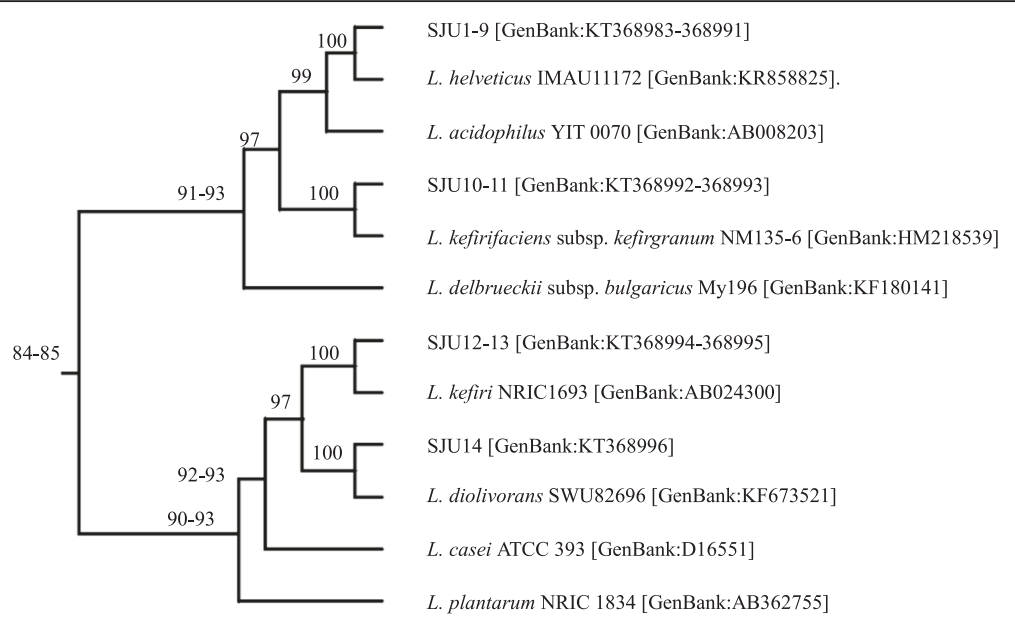

Fig. 2 Rooted phylogenetic tree with branch length of lactobacilli isolated from airag samples and lactobacilli strains in NCBI database. The number in the diagram is percent identity. The word in parenthesis is accession number of nucleotide sequence in NCBI database

\section{Physiological characteristics of lactic acid bacteria} Physiological characteristics of Lactobacillus isolates (Table 2) and Enterococcus isolates (Table 3) were investigated. L. helveticus SJU1-9 were classified into A and $\mathrm{B}$ groups based on carbohydrate fermentation.
Seven isolates (SJU1-7) in the A group fermented fructose, galactose, glucose, lactose and mannose and two isolates (SJU8-9) in the B group fermented additional carbohydrates including maltose, melibiose, salicin, sucrose, and trehalose. L. kefiranfaciens SJU10-11 utilized

Table 2 Carbohydrate fermentation characteristics of lactobacilli isolated from the airag samples

\begin{tabular}{|c|c|c|c|c|c|}
\hline \multirow{3}{*}{$\begin{array}{l}\text { Identification } \\
\text { Groups }\end{array}$} & \multicolumn{2}{|c|}{ L. helveticus } & \multirow[t]{2}{*}{ L. kefiranofaciens } & \multirow[t]{2}{*}{ L. kefiri } & \multirow[t]{2}{*}{ L. diolivorans } \\
\hline & $\bar{A}$ & $B$ & & & \\
\hline & SJU1-7 & SJU8-9 & SJU10-11 & SJU12-13 & SJU14 \\
\hline Arabinose & - & - & - & $(1)^{*}$ & + \\
\hline Cellobiose & - & $(1)^{*}$ & + & - & \\
\hline Fructose & + & + & + & + & + \\
\hline Galactose & + & + & + & + & + \\
\hline Gluconate & - & - & + & - & + \\
\hline Glucose & + & + & + & - & + \\
\hline Lactose & + & + & + & + & + \\
\hline Maltose & - & + & + & + & + \\
\hline Mannitol & - & - & + & - & \\
\hline Mannose & + & + & + & - & \\
\hline Melezitose & & - & + & - & \\
\hline Melibiose & - & + & + & + & + \\
\hline Raffinose & - & - & - & - & - \\
\hline Rhamnose & - & - & - & - & - \\
\hline Ribose & - & - & + & $(1)^{*}$ & - \\
\hline Salicin & - & + & + & - & + \\
\hline Sorbitol & - & - & + & - & \\
\hline Sucrose & - & + & + & - & + \\
\hline Trehalose & - & + & + & - & + \\
\hline Xylose & - & - & - & - & - \\
\hline
\end{tabular}

*The number in parenthesis is the number of positive isolate 
Table 3 Physiological characteristics of enterococci isolated from the airag samples

\begin{tabular}{|c|c|c|c|c|}
\hline \multicolumn{2}{|c|}{ Identification } & \multirow{2}{*}{$\begin{array}{l}\text { E. faecalis } \\
\text { SJU15-16 }\end{array}$} & \multirow{2}{*}{$\begin{array}{l}\text { E. faecium } \\
\text { SJU17 }\end{array}$} & \multirow{2}{*}{$\begin{array}{l}\text { E. durans } \\
\text { SJU18 }\end{array}$} \\
\hline Isolates & & & & \\
\hline \multirow[t]{4}{*}{ Growth at } & $10^{\circ} \mathrm{C}$ & + & + & + \\
\hline & $45^{\circ} \mathrm{C}$ & + & + & - \\
\hline & pH 9.6 & + & + & + \\
\hline & $6.5 \% \mathrm{NaCl}$ & + & + & + \\
\hline \multicolumn{2}{|c|}{$\begin{array}{l}\text { Heat resistance } \\
\text { at } 60^{\circ} \mathrm{C}\end{array}$} & + & + & - \\
\hline \multicolumn{2}{|c|}{$\begin{array}{l}\text { Ammonia from } \\
\text { arginine }\end{array}$} & + & + & + \\
\hline \multicolumn{5}{|c|}{ Fermentation of } \\
\hline & Arabinose & - & - & - \\
\hline & Cellobiose & + & + & + \\
\hline & Fructose & + & + & + \\
\hline & Galactose & + & + & + \\
\hline & Gluconate & + & - & - \\
\hline & Glucose & + & + & + \\
\hline & Lactose & + & + & + \\
\hline & Maltose & + & + & + \\
\hline & Mannitol & + & - & - \\
\hline & Mannose & + & + & + \\
\hline & Melezitose & + & - & - \\
\hline & Melibiose & - & + & - \\
\hline & Raffinose & - & - & - \\
\hline & Rhamnose & - & - & - \\
\hline & Ribose & + & + & + \\
\hline & Salicin & + & + & + \\
\hline & Sorbitol & + & - & - \\
\hline & Sucrose & + & - & - \\
\hline & Trehalose & + & + & - \\
\hline & Xylose & - & - & - \\
\hline
\end{tabular}

16 carbohydrates except arabinose, raffinose, rhamnose and xylose. L. kefiri SJU 12-13 produced acid from fructose, galactose, lactose, maltose and melibiose, but not from glucose. In fact, L. kefiri SJU 12-13 grew poorly in MRS broth but showed heavy growth in MRS broth containing lactose instead of glucose in this study (results not shown). Table 3 showed that all the Enterococcus isolates (SJU15-18) produced ammonia from arginine. E. faecalis SJU15-16 and E. faecium SJU17 grew at $45{ }^{\circ} \mathrm{C}$ and after heat treatment at $60{ }^{\circ} \mathrm{C}$, but $E$. durans SJU18 did not. E. faecalis SJU15-16 produced acid from 15 carbohydrates except arabinose, melibiose, raffinose, rhamnose and xylose. E. faecium SJU17 and E. durans SJU18 produced acid from relatively fewer carbohydrates than E. faecalis SJU15-16.
The physiological characteristics of the isolates of lactobacilli and enterococci described in Table 2 and Table 3, respectively were comparable to those described previously [18, 27, 34]. Sun et al. [8] reported that more than eighty percent of $114 \mathrm{~L}$. helveticus isolates from koumiss in China produced acid from fructose, galactose, lactose, maltose, mannose and sucrose. Two L. kefiranofaciens isolates produced acid from amygdalin, cellobiose, dextrin, fructose, galactose, inositol, inulin, lactose, maltose, mannitol, mannose, melezitose, sarlicin, sorbitol, sucrose and trehalose.

\section{Acid survival and bile resistance}

Acid survival in PBS, pH 3.0 and bile resistance in MRS broth with $0.1 \%$ oxgall (MRS-bile) of isolated lactic acid bacteria were investigated (Table 4). L. helveticus SJU1, SJU5 and SJU7 and L. kefiranofaciens SJU11 showed up to $100 \%$ acid survival. L. helveticus SJU1, SJU5, SJU7 and SJU9 and L. kefiranofaciens SJU11 did not grow in MRS-bile. E, faecalis SJU15 and SJU16 and E. durans SJU18 grew in MRS-bile strongly. E. faecalis SJU15 with moderately strong acid survival and with strong bile resistance seemed to be a good candidate for probiotics in terms of ability to pass through stomach and to multiply in the intestine. Further researches are necessary to isolate appropriate Lactobacillus probiotics from airag.

Many studies have isolated probiotic lactic acid bacteria from airag in Mongolia and koumiss in China based on tolerance in gastrointestinal environment, antimicrobial property and adhesion to cell such as Caco-2 cell $[6,9,35,36]$. Wu et al [6] isolated

Table 4 Acid survival and bile resistance of lactic acid bacteria isolated from the airag samples

\begin{tabular}{llll}
\hline Identification & Isolates & $\begin{array}{l}\text { Acid survival }^{a} \\
\%\end{array}$ & $\begin{array}{l}\text { Bile resistance }^{a} \\
\%\end{array}$ \\
\hline L. helveticus & SJU1 & $115 \pm 11$ & 0 \\
& SJU5 & $103 \pm 21$ & 0 \\
& SJU7 & $98 \pm 27$ & $4 \pm 0$ \\
& SJU9 & $57 \pm 7$ & 0 \\
L. kefiranofaciens & SJU10 & $53 \pm 8$ & $2 \pm 0$ \\
& SJU11 & $131 \pm 56$ & $4 \pm 0$ \\
L. kefiri & SJU12 & $50 \pm 19$ & $11 \pm 2$ \\
L. diolivorans & SJU13 & $72 \pm 35$ & $26 \pm 0$ \\
E. faecalis & SJU14 & $44 \pm 29$ & $49 \pm 7$ \\
& SJU15 & $75 \pm 7$ & $101 \pm 13$ \\
E. faecium & SJU16 & $31 \pm 5$ & $129 \pm 40$ \\
E. durans & SJU17 & $51 \pm 5$ & $30 \pm 0$ \\
\hline SUE18 & $57 \pm 21$ & $119 \pm 1$ \\
\hline
\end{tabular}

${ }^{a}$ mean \pm standard deviation 
potential probiotics through the preliminary tests including resistance to high acid and abilities to grow in MRS with bile salts. L. casei Zhang survived strongly in PBS, pH 3.0 and could grow in MRS broth with $1.0 \%$ bile. Rong et al. [35] isolated L. helveticus NS8 from koumiss in Inner Mongolia, China as a candidate for probiotics which showed higher tolerance to low $\mathrm{pH}(70 \%$ survival rate at $\mathrm{pH} 2)$ and toxic bile salts (65\% survival rate in $0.3 \%$ bile). Takeda et al. [9] reported that $L$. plantarum 05 AM23 isolated from airag samples in Ulaanbaatar, Mongolia showed presumable probiotic characteristics of strong bile acid tolerance, high viability at low $\mathrm{pH}$ and strong adhesion on Caco2 cell. Bilige et al. [36] screened L. helveticus isolates from home-made airag in Mongolia and identified $L$. helveticus MG2-1 which is most effective in tolerance to artificial gastrointestinal juice, sodium taurocholate deconjugation, cholesterol removal and adhesion to Caco-2 cell.

\section{Acid production in skim milk cultures}

Changes of pH (Fig. 3), titratable acidity (Fig. 4) and bacterial number (Table 5) of skim milk cultures of $L$. helvetcius SJU5, L. kefiranofaciens SJU10, L. kefiri SJU12 and E. faecalis SJU16 were investigated. The frozen concentrated cultures were used to inoculate skim milk at the level of $7 \log C F U / m L$. Figs. 3 and 4 showed that all of the lactic acid bacteria produced acid and thus lowered $\mathrm{pH}$ of the skim milk culture faster at $37{ }^{\circ} \mathrm{C}$ than at the lower temperatures of 30 and $25{ }^{\circ} \mathrm{C}$. The skim milk cultures of L. helveticus SJU5 reached $\mathrm{pH} 3.25$ and $2.71 \%$ titratable acidity for 4 days at $37{ }^{\circ} \mathrm{C}$. Neither L. kefiranofaciens SJU10 nor E. faecalis SJU12 reached $\mathrm{pH} 4.5$ for 4 days at $37{ }^{\circ} \mathrm{C}$. Table 5 confirmed that all the numbers of lactic acid bacteria just after inoculation were close to 7 $\log \mathrm{CFU} /$ per $\mathrm{mL}$. These results showed that L. helveticus SJU5 produced lactic acid more than the other three lactic acid bacteria.
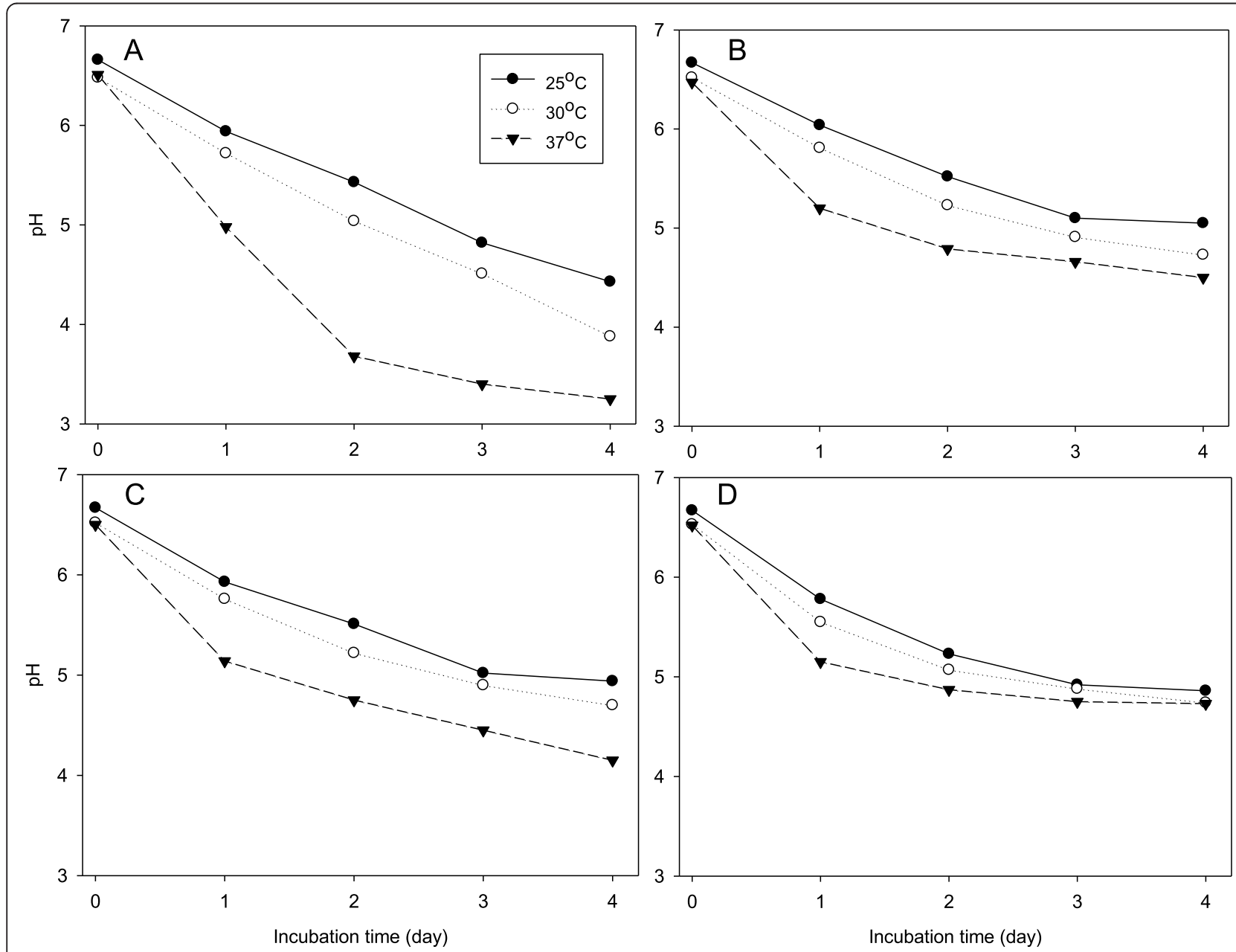

Fig. 3 Change of $\mathrm{pH}$ of skim milk cultures which were inoculated with frozen concentrated cultures of lactic acid bacteria at the level of 7 $\log C F U / \mathrm{mL}$ and incubated at 25,30 and $37^{\circ} \mathrm{C}$. a: L. helveticus SJU5, b: L. kefiranofaciens SJU10, c: L. kefiri SJU12, d: E. faecalis SJU16 


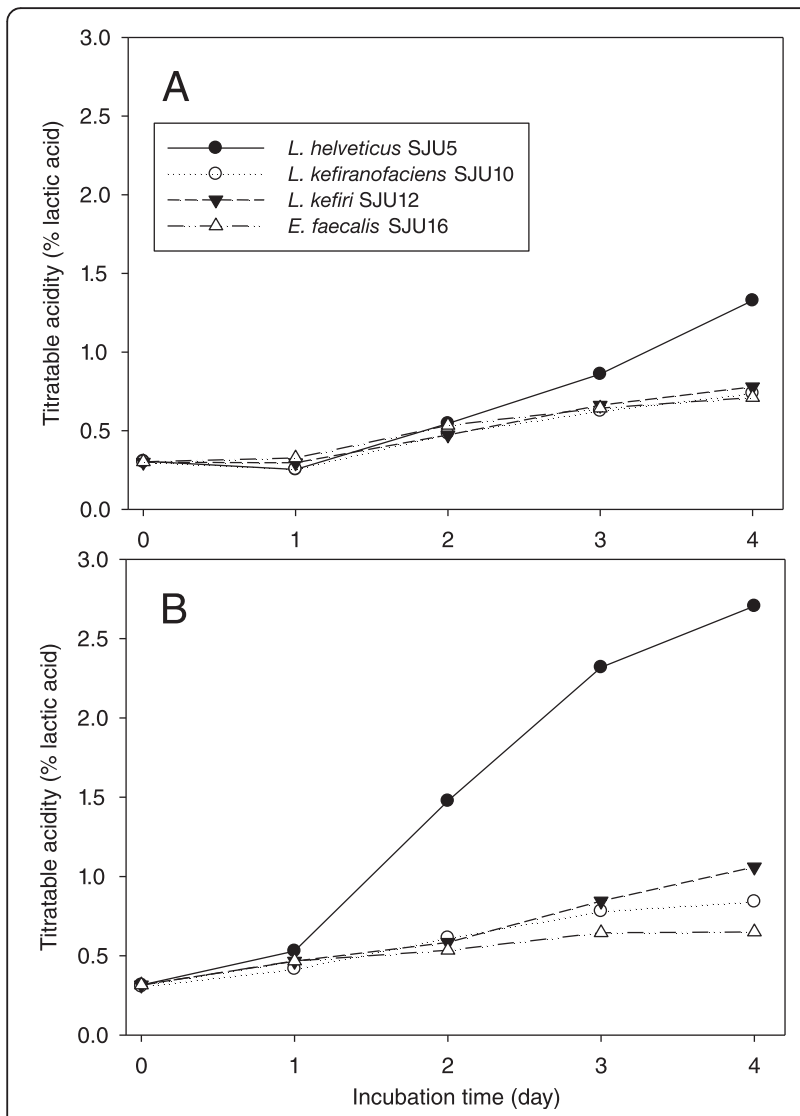

Fig. 4 Change of titratable acidity of skim milk cultures which were inoculated with frozen concentrated cultures of lactic acid bacteria at $7 \mathrm{log} \mathrm{CFU} / \mathrm{mL}$ and incubated at $30^{\circ} \mathrm{C}$ (a) and $37^{\circ} \mathrm{C}$ (b)

Figure 5 showed changes of $\mathrm{pH}$ of skim milk culture at $35{ }^{\circ} \mathrm{C}$ of $L$. helveticus CJU1-6. Two milliliters of activated skim milk cultures were used to inoculate $200 \mathrm{~mL}$ of skim milk which was subsequently incubated to determine $\mathrm{pH}$ changes. L. helveticus CJU2 and CJU5 decreased $\mathrm{pH}$ to 3.76 and 3.71, respectively, for 2 days. These results suggested that L. helveticus CJU2 and CJU5 should have played major roles in producing lactic acid in the airag samples collected in Mongolia in this study.

Wulijideligen et al. [7] reported that L. helveticus I30B4 fermented skim milk at $30{ }^{\circ} \mathrm{C}$ to increase titrable acidity to

Table 5 Growth of lactic acid bacteria during fermentation of skim milk cultures which were inoculated at the level of 7 $\log \mathrm{CFU} / \mathrm{mL}$ and incubated at $25^{\circ} \mathrm{C}$

\begin{tabular}{lllll}
\hline $\begin{array}{l}\text { Incubation } \\
\text { time (day) }\end{array}$ & $\begin{array}{l}\text { L. helveticus SJU5 } \\
\text { (logCFU/mL) }\end{array}$ & $\begin{array}{l}\text { L. } \\
\text { kefiranofaciens } \\
\text { SJU10 }\end{array}$ & $\begin{array}{l}\text { L. kefiri } \\
\text { SJU12 }\end{array}$ & $\begin{array}{l}\text { E. faecalis } \\
\text { SJU16 }\end{array}$ \\
\hline 0 & 6.87 & 6.97 & 6.89 & 6.87 \\
2 & 8.80 & 8.84 & 8.73 & 9.04 \\
4 & 9.07 & 9.79 & 9.17 & 10.05 \\
\hline
\end{tabular}

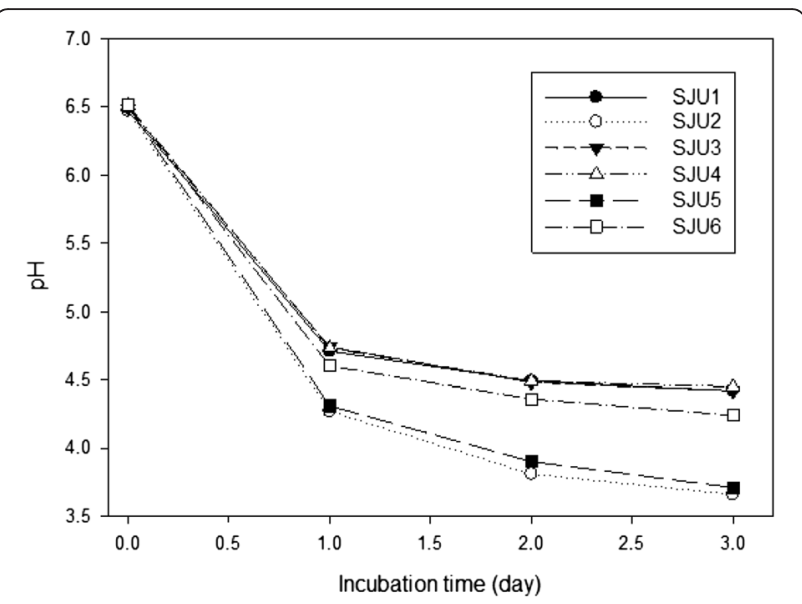

Fig. 5 Change of $\mathrm{pH}$ of skim milk cultures of $\mathrm{L}$. helveticus isolates SJU1-6 which were inoculated with $1 \%$ skim milk cultures and incubated at $35^{\circ} \mathrm{C}$

$2.57 \%$ for 7 days, However, L. plantarum 440 M6, L. casei 6B4084 and L. paracsei 6B3073 increased titratable acidity to $1.41 \%, 1.25 \%$ and $1.26 \%$, respectively. The titratatable acidities of skim milk cultures of L. reuteri $940 \mathrm{~B} 3$ and lactococci did not reach $1.0 \%$. The results in this study also showed that $L$. helveticus was more effective in producing lactic acid during fermentation of skim milk than the other lactic acid bacteria.

L. helveticus, which has been most frequently isolated from airag in Mongolia, is also used traditionally used in cheese-making in Swiss and Italy and is recovered from the natural lactic acid starter cultures used for the production of Italian cheese. It is also gaining potential as health-promoting probiotic in dietary supplement [31]. L. helveticus strains isolated from cheese showed characteristics of rapid lysis and high proteolytic activity [37]. The highly efficient proteolytic system of $L$. helveticus enhances texture and flavor during cheese aging and produces bioactive peptides from milk proteins in fermented milk beverage which may provide beneficial effects on blood pressure, immune system, calcium absorption and anti-virulent effects against pathogens [38]. The strong acid production capacity and proteolytic activity of $L$. helveticus, the major lactic acid bacteria in airag, should enable Mongolian to enjoy flavorful beverage which provide therapeutic benefits as well as essential nutrients.

\section{Conclusions}

The compositions, particularly lactose contents, of the airag samples collected in Ulaanbaatar, Mongolia were variable, showing inconsistent quality due to natural fermentation. The low lactose content of airag may allow Mongolian to consume it in large quantity without suffering from lactose intolerance. Equine whey proteins 
rather than caseins were major proteins in the airag samples. pHs and titratable acidity of all the airag samples were less than 4.0 and more than $1 \%$, respectively, suggesting that airag was strongly sour-tasting. A couple of $L$. helveticus isolated from the airag samples produced lactic acid actively, which suggested that $L$. helveticus should have played a major role in fermentation of mares' milk to produce airag.

\section{Competing interests}

The author declares that he has no competing interests.

\section{Acknowledgement}

This work was supported by a research fund provided by Sangji University in 2013.

Received: 11 August 2015 Accepted: 19 January 2016

Published online: 08 March 2016

\section{References}

1. Koroleva NS. Starters for fermented milks. In: Bulletin 227. Brussels: International Dairy Federation; 1988. p. 35-40.

2. Liu S, Han Y, Zhou Z. Lactic acid bacteria in traditional fermented Chinese foods. Food Res Int. 2011;44:632-61.

3. Mu Z, Yang $X$, Yuan $H$. Detection and identification of wild yeast in Koumiss. Food Microbiol. 2012;33:301-8.

4. Sun ZH, Liu WJ, Zhang J, Yu J, Gao W, Jiri B, et al. Identification and characterization of the dominant lactic acid bacteria isolated from traditional fermented milk in Mongolia. Folia Microbiologica. 2010;55:270-6.

5. Watanabe K, Fujimoto J, Sasamoto M, Dugersuren J, Tumursuh T, Demberel S. Diversity of lactic acid bacteria and yeasts in airag and tarag, traditional fermented milk products of Mongolia. World J Microbiol Biotechnol. 2008; 24:1313-25.

6. Wu R, Wang L, Wang J, Li H, Menghe B, Wu J, et al. Isolation and preliminary probiotic selection of lactobacilli from koumiss in Inner Mongolia. J Basic Microbiol. 2009:49:318-26.

7. Wulijideligen S, Arakawa K, Miyamoto M, Miyamoto T. Interaction between lactic acid bacteria and yeasts in airag, an alcoholic fermented milk. Animal Sci J. 2013;84:66-74

8. Sun Z, Liu W, Zhang J, Yu J, Zhang W, Cai C, et al. Identification and characterization of the dominant lactobacilli isolated from koumiss in China. J Gen Appl Microbiol. 2010;56:257-65.

9. Takeda S, Yamasaki K, Takeshita M, Kikuchi Y, Tsend-Ayush C, Dashnyam B, et al. The investigation of probiotic potential of lactic acid bacteria isolated from traditional Mongolian dairy products. Animal Sci J. 2011:82:571-9.

10. Uchida K, Hirata M, Motoshima H, Urashima T, Arai I. Microbiota of airag, tarag and other kinds of fermented dairy products from nomad in Mongolia. Animal Sci J. 2007;78:650-8.

11. Shuangquan B, Yu B, Miyamoto T. Microflora in traditional starter cultures for fermented milk, hurunge, from Inner Mongolia, China. Animal Sci J. 2006;77:235-41.

12. Donmez N, Kisadere I, Balaban C, Kadiralieva N. Effects of traditional homemade koumiss on some hematological and biochemical characteristics in sedentary men exposed to exercise. Biotech Histochem. 2014;3:1-6.

13. Malacarne M, Martuzzi F, Summer A, Mariani P. Protein and fat composition of mare's milk: nutrional remarks with reference to human and cows' milk. Int Dairy J. 2002;12:869-77.

14. Caspo-Kiss Z, Stefler J, Martin TG, Makray S, Csapo J. Composition of mares' colostrum and milk. Protein content, amino acid composition and contents of macro- and micro-elements. Int Dairy J. 1995;15:403-15.

15. Caspo J, Stefler J, Martin TG, Makray S, Caspoi-Kiss Z. Composition of mares' colostrum and milk. fat content, fatty acid composition and vitamin content. Int Dairy J. 1995;5:393-402.

16. Tharmaraj N, Shah NP. Selective enumeration of Lactobacillus delbrueckii ssp. bulgaricus, Streptococcus thermophiles, Lactobacillus acidophilus, bifidobacteria, Lactobacillus casei, Lactobacillus rhamnosus and propionibacteria. J Dairy Sci. 2003:86:2286-96.
17. Dave RI, Shah NP. Evaluation of media for selective enumeration of Streptococcus thermophiles, Lactobacillus delbureckii ssp. bulgaricus, Lactobacillus acidophilus, and bifidobacteria. J Dairy Sci. 1996;79:1529-36.

18. Harrigan WF, McCane ME. Laboratory methods in food and dairy microbiology. London: Academic; 1976.

19. Bradley Jr RL, Arnold Jr E, Barbano DM, Semerad RG, Smith DE, Vines BK. In: Marshall RT, editor. Standard methods for the examination of dairy products. Baltimore: Port City Press, 1993.

20. Laemmli UK. Cleavage of structural proteins during assembly of the head of bacteriophage T4. Nature. 1970;227:680-5

21. Egito AS, Girardet J-M, Miclo L, Molle D, Humbert G, Gaillard J-L. Susceptibility of equine $\alpha$ - and $\beta$-caseins to hydrolysis by chymosin. Int Dairy J. 2011;11:885-93.

22. Girardet J-M, N'negue M-A, Egito AS, Campagna S, Lagrange A, Gaillard J-L. Multiple forms of equine a-lactalbumin: evidence for N-glycosylated and deamidated forms. Int Dairy J. 2004;14:207-17.

23. Uniacke-Lowe T, Huppertz T, Fox PF. Equine milk proteins: chemistry, structure and nutritional significance. Int Dairy J. 2010;20:609-29.

24. An Y, Adachi Y, Ogawa Y. Classification of lactic acid bacteria isolated from chigee and mare milk collected in inner Mongolia. Anim Sci Technol. 2004; 75:245-52.

25. Varnam AH, Sutherland JP. Milk and milk products - technology, chemistry and microbiology. London: Chapman \& Hall; 1994

26. Danova S, Petrov K, Pavlov P, Petrova P. Isolation and characterization of Lactobacillus strains involved in koumiss fermentation. Inter J Dairy Technol. 2005;58:100-5.

27. Hammes WP, Hertel C. Genus I. Lactobacillus. In: Whitman WB, editor. Bergey's manual of systematic bacteriology vol. 3. The firmicutes. Dordrech: Springer; 2009. p. 465-511.

28. Sanders ME, Klaenhammer TR. The Scientific basis of Lactobacillus acidophilus NCFM functionality as a probiotic. J Dairy Sci. 2001;84:319-31.

29. Chen Y, Liu W, Xue J, Yang J, Chen X, Shao Y, et al. Angiotensin-converting enzyme inhibitory activity of Lactobacillus helveticus strains from traditional fermented dairy foods and antihypertensive effect of fermented milk of strain H9. J Dairy Sci. 2014;97:6680-92.

30. Jauhiainen T, Vapaatalo H, Poussa T, Kyronpalo S, Rasmussen M, Korpela R. Lactobacillus helveticus fermented milk lowers blood pressure in hypertensive subjects in 24-hambulatory blood pressure measurement. Am J Hypertens. 2005;18:1600-5.

31. Giraffa G. Lactobacillus helveticus: importance in food and health. Front Microbiol. 2014:5:338-9.

32. Maeda H, Zhu X, Omura K, Suzuki S, Kitamura S. Effects of an exopolysaccharide (kefiran) on lipids, blood pressure, blood glucose, and constipation. Biofactors. 2004;22:197-200.

33. Uchida M, Ishii I, Inoue C, Akisato Y, Watanabe K, Hosoyama S, et al. Kefiran reduces atherosclerosis in rabbits fed a high cholesterol diet. J Atheroscler Thromb. 2010;17:980-8.

34. Svec P, Devriese LA. Genus I. Enterococcus. In: Whitman WB, editor, Bergey's manual of systematic bacteriology vol. 3. The firmicutes. Springer; 2009. p 594-607.

35. Rong J, Zheng H, Lin M, Hu X, Wang T, Zhnag X, et al. Probiotic and antiinflammatroy attributes of isolated Lactobacillus helveticus NS8 from Mongolian fermented koumiss. BMC Microbiol. 2015;15:196.

36. Bilige $M$, Liu W, Rina W, Wang L, Sun T, Wang J, et al. Evaluation of potentia probiotics properties of the screened lactobacilli isolated from home-made koumiss in Mongolia. Annals Microbiol. 2009:59:493-98.

37. Slattery L, O'Callaghan J, Fitzerald GF, Beresford T, Ross RP. Invited review: Lactobacillus helveticus a thermophilic dairy starter related to gut bacteria. J Dairy Sci. 2010;93:4435-54

38. Griffiths MW, Tellez AM. Lactobacillus helveticus: the proteolytic system. Front Microbiol. 2013:4:1-9. 